\title{
An Insight into the Histopathology of Oral Neoplasms with Basaloid Morphology and a Working Classification
}

Manas Bajpai and Nilesh Pardhe

Department of Oral and Maxillofacial Pathology, NIMS Dental College, Jaipur, India

\section{ABSTRACT}

Basal cell tumors (BCT) are tumors usually derived from pluripotential stem cell compartments of the basal layer of epidermis and/or oral epithelium. BCTs are infrequent entities in the oral cavity and are not discussed separately in general and oral pathology. A literature review did not reveal any classification of tumors with basaloid morphology. This paper is an attempt to categorize the oral neoplasms with basaloid morphology and discuss their differential diagnoses in detail. A review of the literature was carried out to rule out the frequency of different oral BCTs reported in the literature. Additionally, a simple working classification of oral BCTS has been proposed. We hope that this classification will be helpful for oral and general pathologists and students.

Key words: basal cell tumors, basaloid morphology, oral cavity

ISSN 2507-8364 (Online)

Printed in the Philippines.

Copyright $(2) 2017$ by the PJP.

Received: 21 June 2017

Accepted: 10 August 2017

Published online first: 8 September 2017.

https://doi.org/10.21141/PJP.2017.019

Corresponding author: Manas Bajpai, MDS

E-mail:dr.manasbajpai@gmail.com

\section{INTRODUCTION}

Basal cell tumors in the oral cavity are rare. Due to their overlapping histopathological features and admixture of basal cell and squamous cells on histopathological examination, these tumors often produce a diagnostic difficulty for pathologists and oral pathologists. ${ }^{1,2,3}$ At times, an immunohistochemical examination is required to arrive at a final diagnosis. ${ }^{4}$ Some authors also believe that "basaloid" patterns occurring anywhere in the body represent attempts at glandular differentiation. ${ }^{5,6}$ An exhaustive literature review did not reveal any working classification of oral BCTs. A simple working classification of Oral BCTs is proposed here (Table 1). In this proposed working classification, oral BCTs can be classified into tumors of the oral epithelium, minor salivary gland tumors and odontogenic tumors.

\begin{tabular}{|c|c|c|}
\hline S. NO & Origin & Tumors \\
\hline A & $\begin{array}{l}\text { Tumors of } \\
\text { Oral epithelium }\end{array}$ & $\begin{array}{l}\text { 1. Basal cell carcinoma. } \\
\text { 2. Basaloid squamous cell carcinoma }\end{array}$ \\
\hline B & $\begin{array}{l}\text { Tumors of odontogenic } \\
\text { epithelium }\end{array}$ & 1. Basal cell ameloblastoma \\
\hline C & $\begin{array}{l}\text { Minor salivary gland } \\
\text { tumors with basaloid } \\
\text { morphology }\end{array}$ & $\begin{array}{l}\text { 1. Basal cell adenoma. } \\
\text { 2. Basal cell adenocarcinoma. } \\
\text { 3. Adenoid cystic carcinoma (solid type) }\end{array}$ \\
\hline
\end{tabular}

\section{A. Tumors derived from oral epithelium}

\section{Intra-oral basal cell carcinoma (IOBCC)}

Basal cell carcinoma is the most common adnexal tumor; however its occurrence in the oral cavity is rare and controversial. ${ }^{7-10}$ Clinically, they present as non-healing ulcers. Histopathologically, they exhibit numerous tumor islands composed of basaloid cells in the lamina propria (Figure 1). Tumor islands exhibit a prominent palisading of peripheral basal cells (Figure 2). The diagnosis of IOBCC solely on histopathological grounds, however, is not easy, due to their histological resemblance with peripheral ameloblastoma (PA). ${ }^{11,12}$ The differentiation between IOBCG and $\mathrm{PA}$ is of utmost importance since the former is malignant.

Although IOBCG and PA may be distinguished by the presence of reverse polarity in $\mathrm{PA},{ }^{13}$ immunohistochemistry is considered as the 


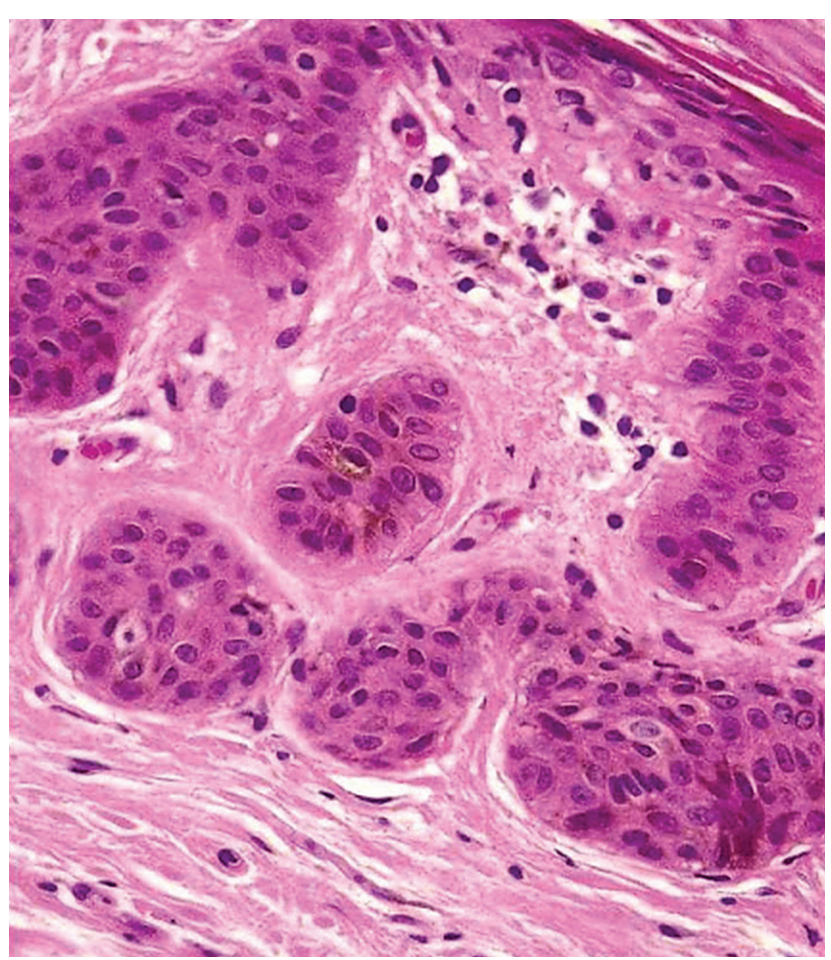

Figure 1. Tumor islands of basal cells in lamina propria (Hematoxylin and eosin stain $\times 20$ ).

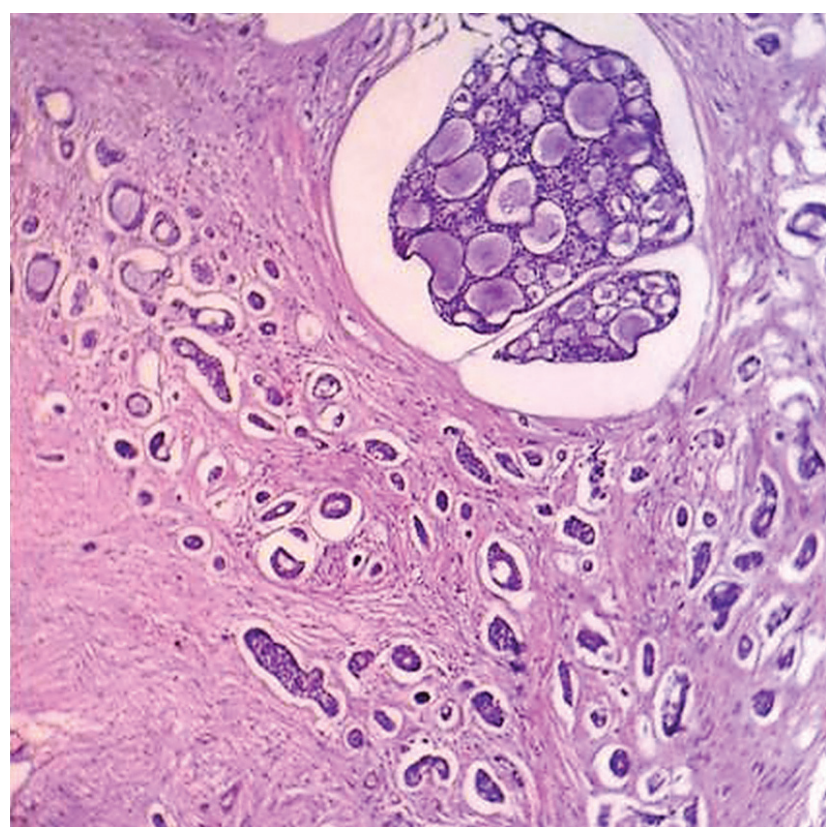

Figure 2. Tumor islands exhibit peripheral palisading (Hematoxylin and eosin stain $\times 40)$.

most reliable means of differentiation. Only 21 cases of IOBCG have been reported in the literature to date. ${ }^{12}$ Some authors believe that earlier reported cases of IOBCG were actually PA. In 2001, Del Rosario, et al. ${ }^{14}$ reported the first well documented case of IOBCG using Ber-EP4, a tumor marker that shows a positive expression for basal cells, supporting its origin from the basal layer of the oral epithelium. Calretinin, a $29 \mathrm{KDa}$ protein, has been found to show positive expression in neoplastic proliferation of ameloblastic epithelium, specifically staining the stellate reticulumlike cells of ameloblastoma. ${ }^{15-17}$ Calretinin is considered as an additional important marker to differentiate PA from IOBCC.

\section{Oral Basaloid Squamous cell carcinoma (OBSCC)}

Basaloid squamous cell carcinoma (BSCG), as defined by the World Health Organization, is an aggressive, high-grade variant of squamous cell carcinoma (SCG), composed of both basaloid and squamous components. ${ }^{18,19}$ BSCCs are common in the oropharynx but rare in the oral cavity. ${ }^{20,21}$ Clinically, they present as indurated masses with central ulceration. ${ }^{21,22}$ Histopathologically, they may resemble the solid variant of adenoid cystic carcinoma (ACC), adenosquamous carcinoma, and small cell neuroendocrine carcinoma $(\mathrm{SGNG}){ }^{21-25}$ BSCG can be differentiated from ACG on the basis of myoepithelial cells and basement membrane-like material (both of which are found in ACG but absent in BSCC). Moreover, the atypia in ACG is less pronounced in comparison to BSCC (Figure 3). ${ }^{23-25}$

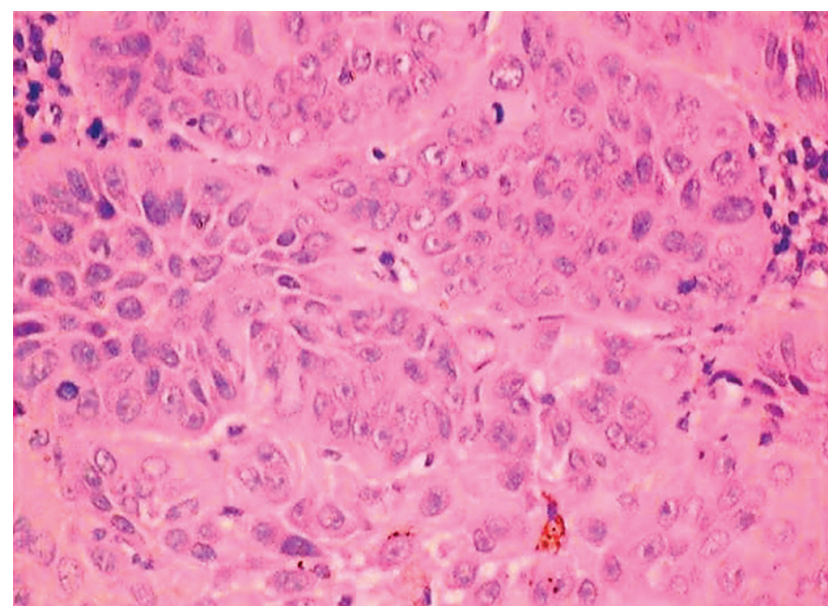

Figure 3. Infiltrating islands of basaloid cells with hyperchromatic nuclei (Hematoxylin and eosin stain x40).

Immunohistochemically, the basement membrane-like material in ACG shows positive expression for laminin and type IV collagen. P63 shows a diffuse positive expression for the tumor cells of BSCC, but is weakly expressed in ACG. ${ }^{24}$ Adenosquamous carcinoma shows true ductal acinar differentiation and mucicarmine positivity ${ }^{23,25-27}$ BSCG does not show these features and can thus be differentiated from adenosquamous carcinoma. ${ }^{24,26-27}$ On the other hand, SCNG shows nuclear molding, hyalinization and crushing artifacts on $\mathrm{H} \& \mathrm{E}$, and immunohistochemically, shows positive expressions for chromogranin and synaptophysin. BSCC is devoid of all of these features. ${ }^{23-24,26}$ Wain's criteria ${ }^{27}$ is an essential parameter to diagnose BSCG. This criteria include both histologic (peripheral palisading associated with SCC, high nuclear-cytoplasmic ratio, high mitotic index, solid growth pattern) and immunohistochemical features (positive expression for anti34BE 1 and cytokeratin 5/6; negative expression for synaptophysin and chromogranin, and Ber-EP4). Occurrence of BSCG in the oral cavity is infrequent and very few case reports were found in the literature. ${ }^{22-23,26}$

A proper diagnosis of Oral BSCG is important in order to plan an appropriate treatment modality, considering its association with poor prognosis.

\section{B. Tumors derived from odontogenic epithelium}

\section{Basal cell ameloblastoma (BCA)}

Ameloblastomas are benign tumors whose importance lies in its potential to grow into enormous size with resulting bone deformity. ${ }^{28}$ Basal cell ameloblastoma is a rare variant of solid 
multicystic ameloblastoma (SMA) with only 11 cases reported in the literature so far. ${ }^{29}$ Clinically they are similar to other histopathological variants of SMA. ${ }^{29-31}$ Histopathologically, they exhibit nests of basaloid cells that show intense basophilic staining. ${ }^{29}$ The stellate reticulum-like cells are absent and central cells may be polyhedral. ${ }^{28,29}$ The nuclear orientation of peripheral cells is different from the other histopathological patterns of ameloblastomas: they are usually cuboidal or columnar and do not show reverse polarity (Figure 4). BCAs show a close resemblance to $\mathrm{BCC}$ on histopathology; however a demarcation can be made on immunohistochemical grounds by using Ber-EP4. ${ }^{29,30}$ The prognosis and biological behavior of BCA is not clear, due to its rarity and very few reported cases.

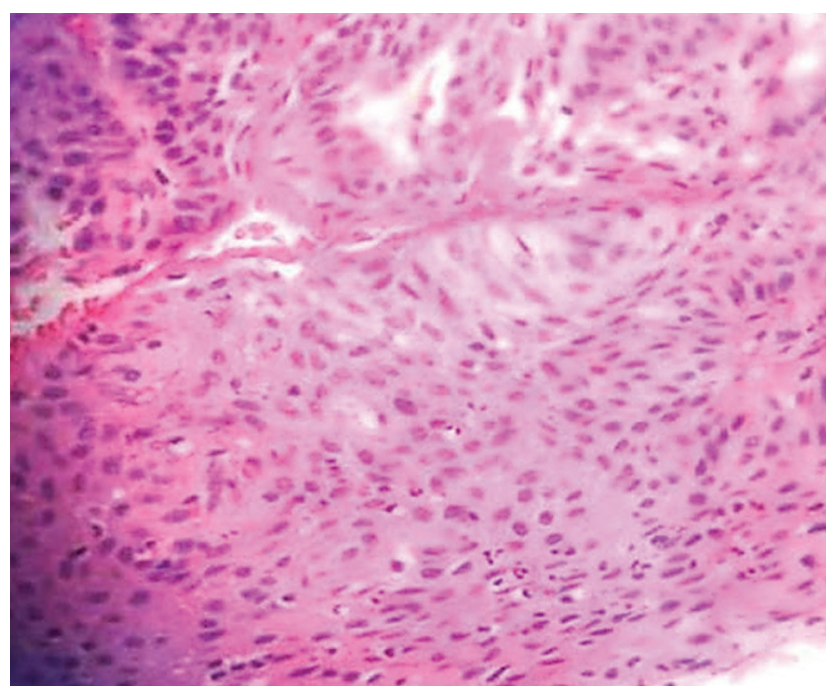

Figure 4. Sheets of basaloid cells with few cells showing highly intense basoliphic staining and peripheral cells with reversal of polarity, the sheets are separated by sparse connective tissue septa. The tissue is lacking stellate reticulum like cells which is the hallmark of ameloblastoma (Hematoxylin and eosin stain $\mathrm{x} 40$ ).

\section{Tumors derived from salivary gland epithelium}

\section{Basal cell adenoma}

Basal cell adenomas (BCA) are rare benign salivary gland tumors, most often originating from the parotid gland. ${ }^{32}$ BCAs originating from the minor salivary glands are comparatively rare and only 13 cases have been reported in the literature. Histopathologically, they are comprised of isomorphic cells similar to basaloid cells with palisading arrangement and distinctive basement membranelike material (Figure 5). BCAs share a close resemblance with canalicular adenoma and Basal cell adenocarcinomas (BCAC). The trabecular-tubular variant of BCA may be misdiagnosed as canalicular adenoma on low power view, and a proper inspection on high power exhibits the presence of both basal and luminal cells with more collagenized stroma compared to canalicular adenoma. ${ }^{33,34}$ BCACs, on the other hand, are not encapsulated and tend to invade the underlying connective tissue stroma. ${ }^{34,35}$

\section{Basal cell adenocarcinoma}

Basal cell adenocarcinomas (BCAC) represent the malignant counterpart of basal cell adenoma, believed to arise from pluripotent ductal reserve cells. ${ }^{36-38}$ Histopathologically, they are characterized by sheets of basaloid cells with hyperchromatic nuclei (Figure 6). Some sheets show peripheral palisading. Some tumors show nests invading the connective tissue stroma. It is necessary to differentiate BCAC from other basaloid cell

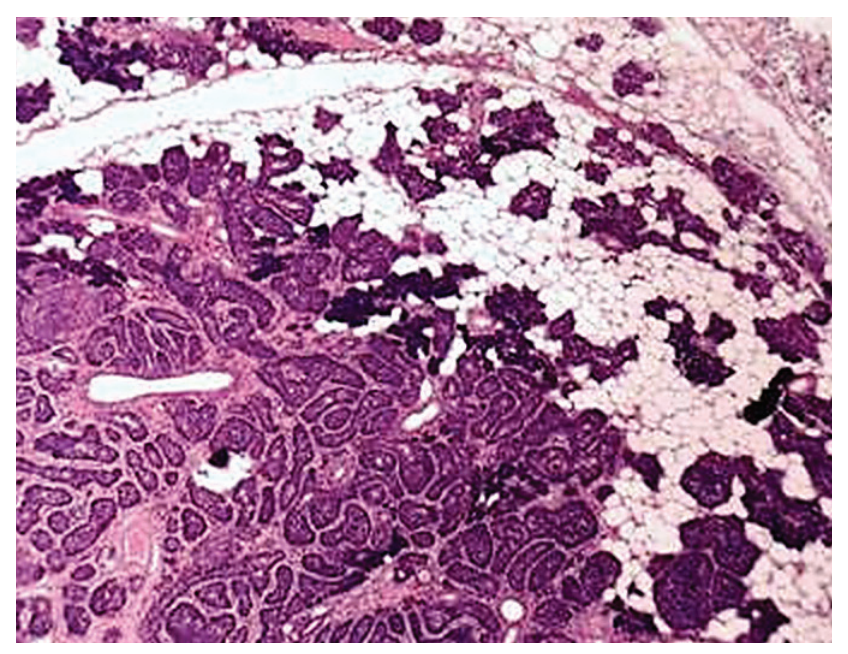

Figure 5. Isomorphic cells similar to basaloid cells with palisading arrangement and distinctive basement membrane like material (Hematoxylin and eosin stain $\times 40$ ).

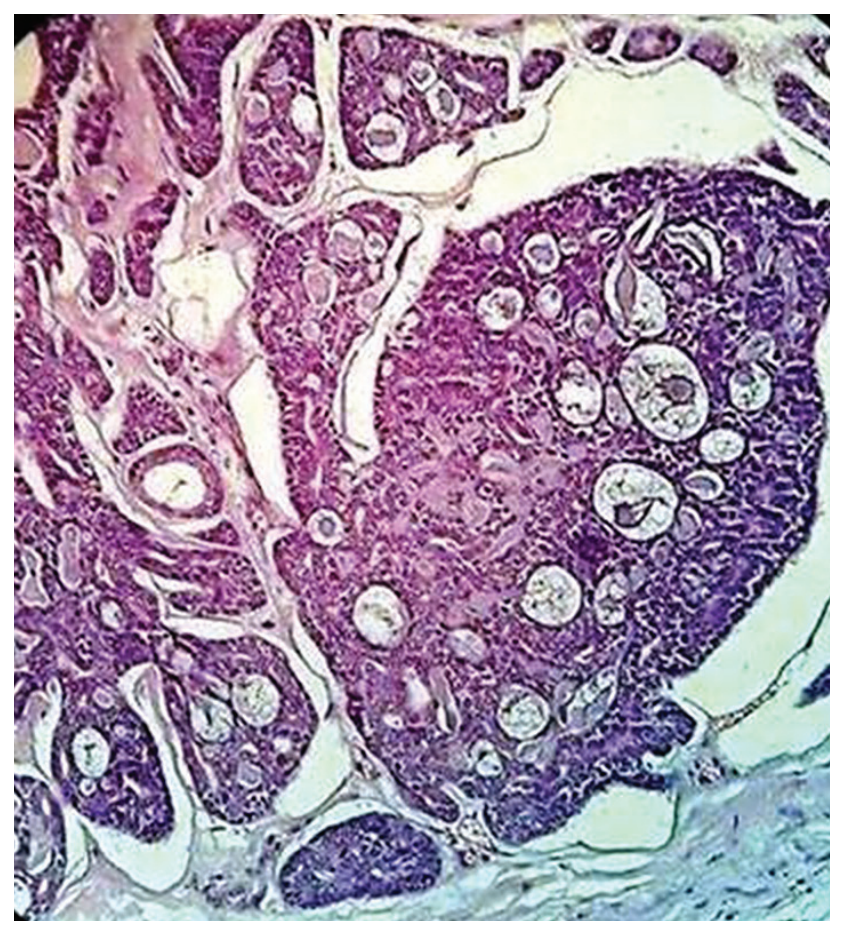

Figure 6. Isomorphic cells similar to basaloid cells with palisading arrangement and distinctive basement membrane like material (Hematoxylin and eosin stain $x 40$ ).

tumors because of the differences in prognosis and potential differences in treatment.

\section{Adenoid cystic carcinoma}

Adenoid cystic carcinoma (ACG) was originally described by Lorain and Laboulbene in 1853. In 1859, Billroth suggested the name cylindroma. ${ }^{39} \mathrm{ACG}$ is a rare tumor, accounting for less than $1 \%$ of all head and neck neoplasms and about $4-10 \%$ of all salivary gland neoplasms. Histopathologically, ACG shows three different patterns, tubular, cribriform and solid. ${ }^{40}$ The solid pattern of ACG is believed to be the most aggressive form with poor prognosis. ${ }^{39}$ Solid ACC is characterized histopathologically by tumor nests or islands completely filled with basaloid cells without cystic spaces. 


\section{CONCLUSION}

It can be concluded that oral BCTs are unusual and may represent diagnostic difficulties on microscopic examination because of their overlapping features. This paper is an attempt to discuss the histopathology and differential diagnosis of various oral neoplasms with basaloid morphology. A simple working classification of oral BCTs has been proposed with the aim of helping pathologists distinguish between various oral entities with basaloid features.

\section{STATEMENT OF AUTHORSHIP}

All authors certified fulfillment of ICMJE authorship criteria.

\section{AUTHOR DISCLOSURE}

The authors declared no conflict of interest.

\section{FUNDING SOURCE}

None.

\section{REFERENCES}

1. Tellechea O, Reis JP, Domingues JC, Baptista AP. Monoclonal antibody Ber-EP4 distinguishes basal-cell carcinoma from squamous- cell carcinoma of the skin. Am J Dermatopathol. 1993;15(15):452-5. PMID: 8238781.

2. Nemade SV, Rokade VV. Basaloid carcinoma: an unusual presentation. Indian J Clin Pract. 2013; 23(11):728-30. http://imsear.hellis.org/handle/123456789/182519.

3. Nagao T, Sugano I, Ishida Y, Hasegawa M, Matsuzaki O, Konno A, et al. Basal cell adenocarcinoma of the salivary glands: comparison with basal cell adenoma through assessment of cell proliferation, apoptosis, and expression of p53 and bcl-2.Cancer. 1998; 82:439-47. PMID: 9452259.

4. Carr RA, Taijbee SM, Sanders DSA. Basaloid skin tumours: basal cell carcinoma. Curr Diagn Pathol. 2007; 13(4):252-72. https://doi.org/10.1016/j.cdip.2007.05.005.

5. Basarab T, Orchard G, Russell-Jones R. The use of immunostaining for bcl-2 and CD34 and the lectin peanut agglutinin in differentiating between basal cell carcinomas and trichoepitheliomas. Am J Dermatopathol 1998; 20(5):448-52. PMID: 9790103.

6. Thariat J, Badoual C, Faure C, Butori C, Marcy PY, Righini CA. Basaloid squamous cell carcinoma of the head and neck: role of HPV and implication in treatment and prognosis. $\mathrm{J}$ Clin Pathol. 2010; 63(10):857-66. PMID: 20876315. https:// doi.org/10.1136/jcp.2010.078154.

7. Bajpai M, Pardhe N, Arora M. Intra-oral basal cell carcinomaan immunohistochemical interpretation using BerEp4. J Ayub Med Coll Abbottabad. 2016; 28(2):438. PMID: 28718582.

8. Mori M, Morimoto Y, Yoshimura Y, Kawamura H. Enzymatic histochemical demonstration of basal-cell carcinoma in the oral cavity. Oral Surg Oral Med Oral Pathol. 1968; 25(5):746-55. PMID: 5239097.

9. Bath-Hextall F, Leonardi-Bee J, Smith C, Meal A, Hubbard R. Trends in incidence of skin basal cell carcinoma. Additional evidence from a UK primary care database study. Int J Cancer. 2007; 121(9):2105-8. PMID: 17640064. https://doi. org/10.1002/ijc.22952.

10. Liroff KP, Zeff S. Basal cell carcinoma of the palatal mucosa. J Oral Surg. 1972; 30(10):730-3. PMID: 4506539.
11. Bajpai M, Pardhe N. Peripheral ameloblastoma with mixed histological patterns. Cukurova Med J. 2015; 40(Suppl 1):151-5. https//doi.org/10.17826/cutf.32647.

12. Woods TR, Cohen DM, Islam MN, Kratochvil FJ, Stewart JC, Reeder SL, et al.. Intraoral basal cell carcinoma, a rare neoplasm: report of three new cases with literature review. Head Neck Pathol. 2014; 8(3):339-48. PMID: 24202723. PMCID: PMC4126916. https://doi.org/10.1007/s12105013-0505-5.

13. Philipsen HP, Reichart PA, Nikai H, Takata T, Kudo Y. Peripheral ameloblastoma: biological profile based on 160 cases from the literature. Oral Oncol. 2001; 37(1):17-27. PMID: 11120479 .

14. Del Rosario RN, Barr RJ, Jensen JL, Cantos KA. Basal cell carcinoma of the buccal mucosa. Am J Dermatopathol. 2001; 23(3):203-5. PMID: 11391100.

15. DeVilliers P, Liu H, Suggs C, Simmons D, Daly B, Zhang $\mathrm{S}$, et al. Calretinin expression in the differential diagnosis of human ameloblastoma and keratocystic odontogenic tumor. Am J Surg Pathol. 2008; 32(2):256-60. PMID: 18223328. https://doi.org/10.1097/PAS.0b013e3181452176.

16. Alaeddini M, Etemad-Moghadam S, Baghaii F. Comparative expression of calretinin in selected odontogenic tumours: a possible relationship to histogenesis. Histopathology. 2008; 52(3):299-304. PMID: 18269580. https://doi.org/ $10.1111 / \mathrm{j} .1365-2559.2007 .02948 . x$.

17. Anandani C, Metgud R, Singh K. Calretinin as a diagnostic adjunct for ameloblastoma. Pathol Res Int. 2014; 2014:308240. PMID: 24839578. PMCID: PMC4009281. https://doi.org/ 10.1155/2014/308240.

18. Ide F, Shimoyama T, Horie N. Basaloid squamous cell carcinoma versus basal cell ameloblastoma. Oral Oncol. 1998; 34(2):154-5. PMID: 9682780.

19. Greene FL, Page DL, Fleming ID, eds. AJCG/UICC cancer staging handbook: TNM classification of malignant tumors. 7th ed. New York: Springer-Verlag, 2009.

20. Ereño C, Gaafar A, Garmendia M, Etxezarraga C, Bilbao FJ, López JI. Basaloid squamous cell carcinoma of the head and neck: a clinicopathological and follow-up study of 40 cases and review of the literature. Head Neck Pathol. 2008; 2(2):83-91. PMID: 20614328. PMCID: PMC2807543. https://doi/org/10.1007/s12105-008-0045-6.

21. Patil AV, Tupsakhare SD, Shah K, Gabhane M, Ali FM. Basaloid squamous cell carcinoma of gingiva: a new case and review of literature. Am J Cancer Case Rep. 2014; 2:99-107.

22. Sundharam BS, Krishnan PA. Basaloid squamous cell carcinoma report of a case and review of literature. Indian J Dent Res. 2003;14(3):184-6. PMID: 15164662.

23. Ide F, Shimoyama T, Horie N. Kusama K. Basaloid squamous cell carcinoma of the oral mucosa: a new case and review of 45 cases in the literature. Oral Oncol. 2002; 38(1):120-4. PMID: 11755833.

24. Emanuel P, Wang B, Wu M, Burstein DE. Immunohistochemistry in the distinction of adenoid cystic carcinoma from basaloid squamous cell carcinoma. Mod Pathol. 2005; 18(5):645-50. PMID: 15529180. https://doi. org/10.1038/modpathol.3800329.

25. Begum S, Westra WH. Basaloid squamous cell carcinoma of the head and neck is a mixed variant that can be further resolved by HPV status. Am J Surg Pathol. 2008; 32(7):1044-50. PMID: 18496144. https://doi.org/10.1097/ PAS.0b013e31816380ec.

26. Vasudev P, Boutross-Tadross O, Radhi J. Basaloid squamous cell carcinoma: two case reports. Cases J. 2009; 2:9351. 
PMID: 20062602. PMCID: PMC2804002. https://doi. org/10.1186/1757-1626-2-9351.

27. Wain SL, Kier R, Vollmer RT, Bossen EH. Basaloid-squamous carcinoma of the tongue, hypopharynx, and larynx: report of 10 cases. Hum Pathol. 1986; 17(11):1158-66. PMID: 3770734 .

28. Bajpai M, Agarwal D, Bhalla A, Kumar M, Garg R, Kumar M. Multilocular unicystic ameloblastoma of mandible. Case Rep Dent 2013; 2013:835892. PMID: 24106618. PMCID: PMC3782764. https://doi.org/ 10.1155/2013/835892.

29. Kramer IR, Pindborg JJ, Shear M. histological typing of odontogenic tumors, 2nd ed. Berlin: Springer-Verlag, 1992.

30. Saify F, Sharma N. Basal cell ameloblastoma: a rare case report and review of literature. Oral Maxillofac Pathol J 2010; 1:1-7. http://www.ompj.org/files/ b9724b4e67cc8a4760a2004b52b6550a-fatima.pdf.

31. Shakya H, Khare V, Pardhe N, Mathur E, Chouhan M. Basal cell ameloblastoma of mandible: a rare case report with review. Case Rep Dent. 2013; 2013:187820. PMID: 23653864. PMCID: PMC3638548. https://doi. org/10.1155/2013/187820.

32. Chiu NC, Wu HM, Chou YH, Li WY, Chiou YY, Guo WY, et al. Basal cell adenoma versus pleomorphic adenoma of the parotid gland. AJR Am J Roentgenol. 2007; 189(5): W254-1. PMID: 17954621. https://doi.org/10.2214/AJR.07.2292.

33. Batsakis JG, Luna MA, el-Naggar AK. Basaloid monomorphic adenomas. Ann Otol Rhinol Laryngol. 1991; 100(8):687-90. PMID: 1872522. https://doi. org/10.1177/000348949110000818.
34. Bajpai M. Canalicular adenoma arising in buccal mucosa. J Coll Physician Surg Pak. 2016; 26(11):46. PMID: 27981939.

35. Fonseca I, Soares J. Basal cell adenocarcinoma of minor salivary and seromucous glands of the head and neck region. Semin Diagn Pathol. 1996; 13(2):128-37. PMID: 8734419.

36. Hirsch DL, Miles C, Dierks E. Basal cell adenocarcinoma of the parotid gland: report of a case and review of the literature. J Oral Maxillofac Surg. 2007; 65(11):2385-8. PMID: 17954345. https://doi.org/10.1016/j.joms.2006.07.021.

37. Parashar P, Baron E, Papadimitriou JC, Ord RA, Nikitakis NG: Basal cell adenocarcinoma of the oral minor salivary glands: review of the literature and presentation of two cases. Oral Surg Oral Med Oral Pathol Oral Radiol Endod. 2007, 103(1):77-84. PMID: 17178498. https://doi.org/10.1016/j. tripleo.2005.12.021.

38. Jung MJ, Roh JL, Choi SH, Nam SY, Kim SY, Lee SW, et al. Basal cell adenocarcinoma of the salivary gland: a morphological and immunohistochemical comparison with basal cell adenoma with and without capsular invasion. Diagn Pathol. 2013; 8:171. PMID: 24143938. PMCID: PMC4016524. https://doi.org/10.1186/1746-1596-8-171.

39. Martínez-Rodríguez N, Leco-Berrocal I, Rubio-Alonso L, Arias-Irimia O, Martínez-González JM. Epidemiology and treatment of adenoid cystic carcinoma of the minor salivary glands: a meta-analytic study. Med Oral Patol Oral Cir Bucal. 2011; 16(7):e884-9. PMID: 21743416.

40. Eneroth CM, Hjertman L, Moberger G. Adenoid cystic carcinoma of the palate. Acta Otolaryngol.1968; 66(3):24860. PMID: 4303189.

\footnotetext{
Disclaimer: This journal is OPEN ACCESS, providing immediate access to its content on the principle that making research freely available to the public supports a greater global exchange of knowledge. As a requirement for submission to the PJP, all authors have accomplished an AUTHOR FORM, which declares that the ICMJE criteria for authorship have been met by each author listed, that the article represents original material, has not been published, accepted for publication in other journals, or concurrently submitted to other journals, and that all funding and conflicts of interest have been declared. Consent forms have been secured for the publication of information about patients or cases; otherwise, authors have declared that all means have been exhausted for securing consent.
} 